No2/2012

ENVIRONMENTAL LAW NETWORK INTERNATIONAL

RÉSEAU INTERNATIONAL DE DROIT DE L'ENVIRONNEMENT

INTERNATIONALES NETZWERK UMWELTRECHT

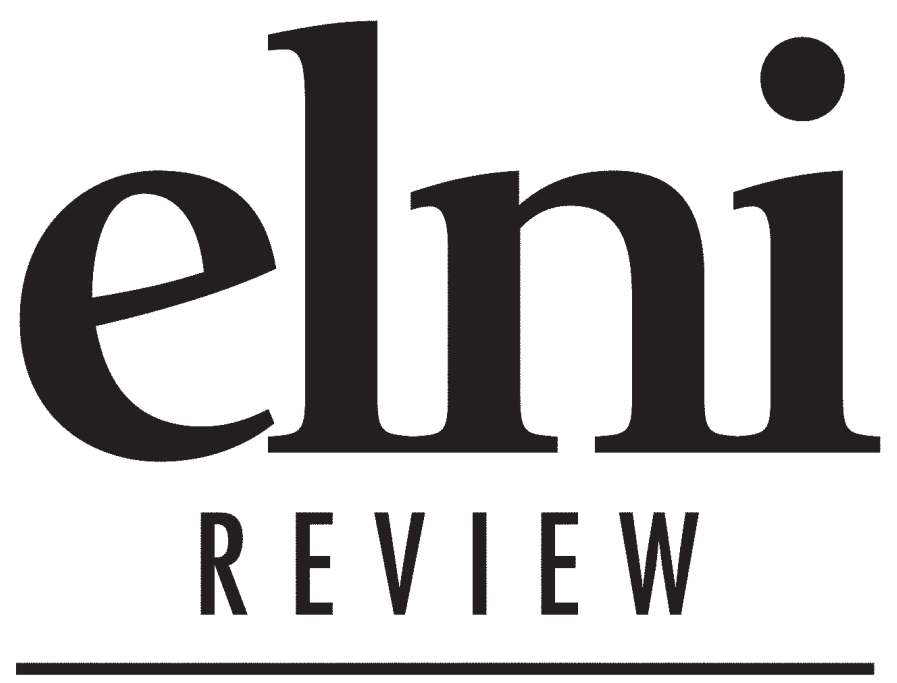

Nanomaterials as priority substances under the Water Framework Directive

Catherine Ganzleben / Steffen Foss Hansen

The Marine Strategy Framework Directive and its implementation in Spain

Ana Barreira

Hong Kong Convention and EU Ship Recycling Regulation: Can they change bad industrial practices soon?

Thomas Ormond

Water services and why a broad definition under the WFD is needed to ensure the polluter pays principle Sarolta Tripolszky

Downsizing our Water Footprint Marga Robesin

The outcome of the UN Conference on

Sustainable Development "Rio+20": Some critical comments Eckard Rehbinder

Greening the Constitution. The principle of sustainable development anchored in the Belgian Constitution

Peter De Smedt / Hendrik Schoukens / Tania Van Laer

Law and innovation in the context of nanomaterials: Barriers to sustainable development?

Julian Schenten / Martin Führ

And further articles 


\section{CONIENTS}

Editorial

\section{Articles within the focus}

Nanomaterials as priority substances under the Water Framework Directive

Catherine Ganzleben and Steffen Foss Hansen

The legal protection of the marine environment:

The Marine Strategy Framework Directive and its implementation in Spain.....

Ana Barreira

Hong Kong Convention and EU Ship Recycling Regulation: Can they change bad industrial practices soon?

Thomas Ormond

Water services and why a broad definition under the WFD is needed to ensure the polluter pays principle....

Sarolta Tripolszky

Downsizing our Water Footprint

Marga Robesin

\section{Articles with focus on other topics}

The outcome of the UN Conference on Sustainable Development "Rio+20": Some critical comments

Eckard Rehbinder

Greening the Constitution. The principle of sustainable development anchored in the Belgian Constitution.

Peter De Smedt, Hendrik Schoukens and Tania Van Laer

Law and innovation in the context of nanomaterials: Barriers to sustainable development?

Results of an empirical study.....

Julian Schenten and Martin Führ

A first success in the long run for better access to justice in the EU: The scope of the administrative review procedure provided under Regulation 1367/2006 invalidated by the General Court.

Anaïs Berthier

\section{Statement}

Bank rescues in place of world rescue: Government heads knowingly failed at the Rio+20 summit.

Almut Gaude (BUND)

\section{Upcoming Events}

20 years of Habitats Directive: European Wildlife's Best Hope?

International Conference - Antwerp, 12-13 December 2012.

Imprint 


\section{Editorial}

Water is a precondition for human, animal and plant life as well as an indispensable resource for the economy. Thus, according to the European Commission the protection of water resources, of fresh and salt water ecosystems and of the water we drink and bathe in is therefore one of the cornerstones of environmental protection in Europe. Against this background the present issue of elni Review focuses on the legal framework for (the protection of) water in Europe and explains, among other things, how far it can cope with possible threats from emerging technologies and to what extent some of the legislation has been implemented in specific member States of the EU. Moreover, insights are provided into some new political or scientific initiatives to further develop the legal framework for protecting water.

First off, Catherine Ganzleben and Steffen Foss Hansen examine whether Directive 2000/60/EC ('Water Framework Directive', WFD), which aims to reduce and minimise the concentrations of dangerous chemicals in European waters, and related legal requirements include the right instruments to capture nanomaterials. They also consider whether techniques are available to allow for monitoring nanomaterials in surface waters and review data from modelling exercises that estimate concentrations of nanomaterials in EU waters.

Subsequently, Ana Barreira provides an overview of the main elements of the Union's Marine Strategy Framework Directive (MSFD) and analyses how Spain, as an EU country with $8000 \mathrm{~km}$ of coastal fringe, is complying with the directive and will review its marine governance framework.

The third article is by Thomas Ormond and takes another perspective, evaluating how far international and European legal instruments for the regulation of ship dismantling (potentially) ensure the safe and environmentally sound recycling of European ships in regions like South Asia.

Sarolta Tripolszky explains the concept of the term 'water services' in her contribution and outlines the economic and legal consequences of a narrow and broad definition. In this context and with specific reference to a collective complaint started by the NGOs EEB and WWF in 2006 against 11 EU member states to enforce the correct implementation of the WFD, she also describes the development of this legal instrument.

The final article with a focus on water is by Marga Robesin and describes current discussions on the question of how to achieve substantial water footprint reduction, focusing in particular on certification and labelling.
A second series of contributions to this issue of the elni Review covers a variety of other up-to-date legal issues, including the advancement and legal implementation of the concept of 'sustainable development'. To this end, Eckard Rehbinder, who attended the United Nations Conference on Sustainable Development $(\mathrm{Rio}+20)$ in Rio de Janeiro in June 2012, shares some critical comments on the summit outcome.

The following contribution by Peter de Smedt, Hendrik Schoukens and Tania Van Laer examines the anchoring of sustainable development in the Belgian Constitution, discusses the concept's juridical enforceability and subsequently analyses the consequences of this qualification for the application in the jurisprudence.

In a further article Julian Schenten and Martin Führ present empirical data obtained by several survey methods focusing on companies which manufacture and/or use nanomaterials. They analyse the findings under the perspective of the degree to which REACH (Regulation EC 1907/2006) promotes innovations for sustainability in the field of nanomaterials.

In June 2012 the EU General Court adopted long awaited decisions in two cases in which it interprets for the first time Regulation 1367/2006 ('Aarhus Regulation') - Anaïs Berthier examines what real added value these two decisions have with regards to access to justice.

Finally, in a statement by Almut Gaude from BUND, the German branch of Friends of the Earth (FoE), the NGO expresses its perspective on the Rio +20 conference outcome.

We hope you enjoy reading the current journal. Contributions for the next issue of the elni Review are very welcome and may be sent to the editors by mid-February 2013.

\section{Julian Schenten/Martin Führ}




\title{
Downsizing our Water Footprint
}

\author{
Marga Robesin
}

\section{Introduction}

'Curiosity', the mobile laboratory that landed on Mars in August 2012 ${ }^{1}$, continues the search for life on that planet. Water is a very important indicator in this seeking, because life as we know it is not possible without water. At this moment the 'red planet' seems to be dry, without accessible liquid water. On Earth, the 'blue planet', liquid water is abundantly present. However, despite this abundance 884 million people are without adequate access to clean drinking water and 2.6 billion people lack access to basic sanitary services. Due to preventable water and sanitationrelated diseases an average of 5.000 children dies each day. ${ }^{2}$ This is not only caused by the absence of local adequate water infrastructure, but also by regional water scarcity. $^{3}$

In the near future the problem of water scarcity will even increase in several regions of the world because of factors like a growing world population and climate change. How can we stop this fatal trend?

Left aside the need for a better water infrastructure and other measures to improve access to clean drinking water and sanitary services, the global water demand needs to be reduced. Not only for the sake of people, but also for the protection of ecosystems and biodiversity. Using water saving showerheads in our households is not enough to achieve substantial water use reduction. In the past decade scientists have developed methods to calculate our water footprint on the world. ${ }^{4}$ In 2011 the Global Standard for Water Footprint Assessment, developed by the Water Footprint Network (WFN) was published. ${ }^{5}$

1 http://www.nasa.gov/mission_pages/msl/index.html (Retrieved from Nasa September 2012).

2 http://www.un.org/en/sustainablefuture/water.shtml (Retrieved from UN, May 1, 2012); Progress on drinking Water and Sanitation, 2012 update. WHO/UNICEF Joint Monitoring Programme for Water Supply and Sanitation. ISBN 978-924-1503297.

3 Managing water under uncertainty and risk. World Water Development Report (WWDR) 4, volume 1, ISBN 978-92-3-104235-5, UNESCO 2012, p. 42-44, including fig. 9.1: Key drivers and causal links affecting water stress and sustainability and human well-being.

4 A. Y. Hoekstra (ed). Virtual water trade: Proceedings of the International Expert Meeting on Virtual Water Trade, 12-13 December 2002, Value of Water Research Report Series No. 12, UNESCO-IHE, Delft. www.waterfootprint.org/Reports/Report12.pdf Retrieved from Waterfootprint.

5 A.Y. Hoekstra et al. The Water footprint assessment manual: setting the global standard. Earthscan, 2011, ISBN 978-1-84971-279-8. http://www.waterfootprint.org/?page=files/WaterFootprintAssessmentManual P. 194: 'The water footprint is an indicator of freshwater use that looks at both direct and indirect water use of a consumer or a producer. The wate footprint of an individual, community or business is defined as the total volume of freshwater used to produce the goods and services consumed by the individual or produced by the business.' (Retrieved from waterfootprint, May 1, 2012).
It shows that the major part of our water footprint (WF) consists of water that is used for the production of our food and other products we consume. Famous examples are the 15.000 litres water needed to produce one $\mathrm{kg}$ beef or the fact that 140 litres water are used for the production of one (Dutch) cup of coffee. $^{6}$

Reduction of humanity's water footprint is urgently needed in order to keep water use within the boundaries of our planet. ${ }^{7}$ This article intends to give a short overview of current discussions on the question how to achieve substantial water footprint reduction, focussing in particular on certification and labelling.

\section{A sustainable water footprint?}

Lack of freshwater is partly caused by physical circumstances: most of Earth's water is salt. Only 2.5 per cent of the global water resources consist of freshwater and the major part of these freshwater resources is locked in polar ice, glaciers and deep aquifers. ${ }^{8}$ Only less than 1 per cent is accessible for human use. Precipitation varies with time and place. So freshwater is not unlimitedly available. ${ }^{9}$ Furthermore political and economic circumstances (such as war and poverty) add to the problem of water scarcity in many places. Population growth in combination with industrialisation and urbanisation, changes in consumption pattern ${ }^{10}$ and water pollution will further increase world's demand for water. At this moment (2012) water demand is projected to increase globally by $55 \%$ between 2000 and 2050 .

6 Chapagain, A.K., and Hoekstra, A.Y. (2007) The water footprint of coffee and tea consumption in the Netherlands, Ecological Economics 64(1): 109118.

7 State of the Planet Declaration by the Conference Planet under Pressure, March $2012 \quad$ in http://www.planetunderpressure2012.net/pdf/state_of_planet_declaration.pd f.

8 http://www.unwater.org/statistics_res.html (Retrieved from Unwater, May 5, 2012).

9 Scarcity in a sea of plenty? Global resource scarcities and policies in the European Union and the Netherlands. PBL Netherlands Environmental Assessment Agency. The Hague, 2011, p. 38.

10 If the consumption patterns in upcoming economies like China and India change to that of the USA these countries will be facing severe water scarcity in the future and will probably be unable to sustain their current high degree of water self-sufficiency. A. Hoekstra and A. Chapagain. Globalization of Water. Sharing the Planet's Freshwater Resources. Blackwell Publishing, 2008, p. 134. 


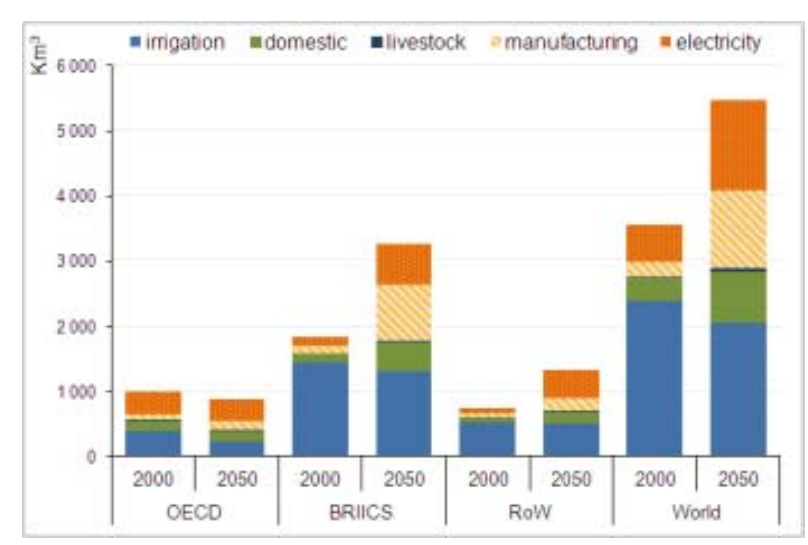

Fig. 1. Global water demand: Baseline scenario, 2000 and 2050 (Note: BRIICS: Brazil, Russia, India, Indonesia, China, South Africa. RoW: Rest of the world.) ${ }^{11}$

This is expected to result in a doubling of the number of people living under conditions of severe water stress in a scenario describing possible trends in the absence of strengthened policies. ${ }^{12}$

How can we bend these trends? Reduction of humanity's water footprint is an important factor. But what is a sustainable global water footprint?

The current one is 7.450 billion $\mathrm{m}^{3}$ water per year. The annual volume of precipitation over land is also roughly known, so a simple lawyer like me may think that it should not be too difficult to calculate a global WF that does not exceed the available freshwater capacity on Earth. For carbon a maximum global sustainable footprint has been set, based on the assumption that global temperature should rise not more than 2 degrees. ${ }^{13}$ For the global water footprint this has not been done yet. Reasons for this are that 1) in contrast to the carbon footprint, the water footprint has geographical dimensions; 2) not all precipitation can be used productively; 3 ) it is not clear what part of the total evapotranspiration on land may be counted as potentially productive and 4) the maximum water footprint depends on the assumed level of

11 Source: The Environmental Outlook Baseline; output from IMAGE model suite; retrieved from: http://www.oecd.org/dataoecd/58/60/49844953.pdf.

12 Water-use effiency measures and irrigation reduction will reduce this number, but not radically, due to the fact that the population in many basins already under severe water stress today is projected to grow strongly until 2050.PBL Netherlands Environmental Assessment Agency. Roads from Rio. Pathways to achieve global sustainability goals by 2050: Summary and Main Findings to the full report; The Hague, 2012 ISBN: 978-90-78645-98-6, PBL publication number: 500062001 (2012), p. 36. Full report: PBL Roads from Rio+20. Pathways to achieve global sustainability goals by 2050 , The Hague, June 2012, ISBN: 978-94-91506-00-0, PBL publication number: 500213001, p. $195 . \quad$ Viewed at http://www.pbl.nl/sites/default/files/cms/publicaties/pbl-2012-roads-from-riopathways-to-achieve-global-sustainability-goals-by-2050_0.pdf.

13 Growing within Limits. A Report to the Global Assembly 2009 of the Club of Rome. Netherlands Environmental Agency (PBL), Bilthoven, October 2009. PBL publication number 500201001, p. 10-11. technology. ${ }^{14}$ 'More crop per drop', i.e. raising water productivity, will lead to a higher maximum capacity. ${ }^{15}$

\section{Every drop counts}

Water footprints can be assessed at several levels: for Earth, a nation, a business, a product or an individual consumer. ${ }^{16}$ Between 1996 and 2005 the global average water footprint per person was $1,385 \mathrm{~m}^{3} /$ year. In the USA the average WF per person is around $2,800 \mathrm{~m}^{3} /$ year and the Chinese is about $1.000 \mathrm{~m}^{3} /$ year now (but used to be $700 \mathrm{~m}^{3} /$ year, so China is catching up with the global average). ${ }^{17}$ For carbon a sustainable footprint has not only been calculated at a global level, but also per person: in 2050 emissions of greenhouse gases (GHG) will need to be about two tonnes per capita per year or less in order to meet the emission reduction targets to avoid dangerous climate change. ${ }^{18}$ With regard to GHG emissions it is irrelevant where they are emitted. As mentioned above the water footprint however has geographical dimensions. In some parts of the world people and ecosystems suffer from water scarcity and in other parts the availability of water is no problem at all. So to be sustainable, it is not sufficient that a consumer's water footprint remains below the equal share of the available freshwater resources in the world. It is also necessary that no component of the water footprint presses at hotspots in place or time where or when local environmental flow requirements are violated. This also counts for the impact on biodiversity, although the water footprint does not measure this impact directly and does not specify how much overshoot must be reduced to avoid negative impacts on biodiversity. ${ }^{19}$

To solve urgent water scarcity problems priority should be given to reducing water footprints located in hotspots, but it is also important to reduce water footprints per ton of product everywhere when possible, also in water-abundant areas. ${ }^{20}$ Every drop

14 Hoekstra, A.Y. (2006) 'The global dimension of water governance: Nine reasons for global arrangements in order to cope with local water problems', Value of Water Research Series No. 20, UNESCO-IHE, p. 18, Globalization, p. 140.

15 Jacob W. Kijne. Unlocking the water potential of agriculture. FAO, 2003. Viewed at: ftp://ftp.fao.org/ag//aglw/docs/unlocking_e.pdf (May 6, 2012)

16 The Water Footprint Assessment Manual, p. 194.

17 http://www.waterfootprint.org/?page=files/WaterFootprintsNations Viewed 9 October 2012.

18 Met Recht naar Klimaatbescherming. Over de rol van het recht en de markt voor het klimaatbeleid. Prof. Marjan Peeters. Maastricht 2009, p. 28.

19 Living Planet Report 2010. WWF 2011, p. 106.

20 The Water Footprint Assessment Manual, p. 102: "from a global point of view reducing the water footprint by $1 \mathrm{~m}^{3}$ in one catchment is equivalent to reducing the water footprint by the same amount in another catchment, even if one catchment shows a much higher water scarcity or water pollution level than the other one. The reason is that - given the limited freshwater resources available worldwide - any reduction contributes to reducing the total resource demand. When, in water-rich catchments, one can produce 
counts: "all water footprint reductions contribute to solving the global problem of an overshoot of limited freshwater resources" 21

\section{Water footprint indicators and targets}

How can we achieve these water footprint reductions as fast and efficient as possible?

Since the products we consume cause by far the major part of our water footprint, the water footprint of products seems the most appropriate point of impact. Reduction of the water footprint of products that have a large footprint and are consumed in large volumes will contribute substantially to reducing individual's footprints and, eventually, to reducing the water footprint of nations and humanity.

The assessment of a product's water footprint and the selection of relevant products require a clear and uniform indicator for the water use caused by production and consumption of a product in the entire supply chain.

At this moment different methods for measuring indirect (or 'virtual') water use are being developed and used, such as the above mentioned Water Footprint Assessment (WFA), Life Cycle Assessment (LCA) and CDP Water (Carbon Disclosure Project) ${ }^{22}$. The main difference between WFA and LCA is their scope. "LCA includes all the supply chain and provides a generalised picture, while WFA looks at single cases after identifying hotspots on a volumetric basis. In that way WFA also looks at the sustainability of water allocation from sustainability, equity and efficiency perspectives at the river-basin level and beyond." 23

The European Commission will use the water footprint or 'embodied water' as indicators for water from a consumption or global supply chain perspective. $^{24}$

more water-intensive goods with the same volume of water, the production of water-intensive goods in water-poor areas can be lessened, so that the total water footprint in those water-poor areas can be reduced. This is an indirect, but important way of solving the pressure on the water resources in water-poor areas."

21 The Water Footprint Assessment Manual, p. 103.

22 https://www.cdproject.net/en-US/Programmes/Pages/cdp-waterdisclosure.aspx.

23 UNEP (2012) Measuring water use in a green economy, A Report of the Working Group on Water Efficiency to the International Resource Panel. McGlade, J. et al. ISBN 978-92-807-3220-7, p. 70. Retrieved from: http://www.unep.org/resourcepanel/Portals/24102/Measuring_Water.pdf.

24 Analysis associated with the Roadmap to a Resource Efficient Europe Part II, Brussels, 20.9.2011, SEC(2011) 1067 final, p. 66-68. In this Analysis a list of possible indicators for resource efficiency was set out. The lead indicator that the European Commission will use in the near future is 'Resource Productivity': Gross Domestic Product (GDP)/Domestic Material Use (DMC) expressed in euro/tonne. To compensate for the limitation in scope of DMC, this lead indicator will be complemented by a 'dashboard' of macro indicators on water, land and carbon. New indicators on natural ecological capital and on environmental impacts of resource use will be added as soon as possible.
The Commission is also developing a harmonised European methodology for Environmental Footprint studies and has drafted a Product Environmental Footprint Guide in cooperation with the Joint Research Centre. ${ }^{25}$ This guide however has been criticised by ANEC, the European Association for the Coordination of Consumer Representation in Standardisation. ANEC advocates a tailored approach, using a choice of indicators and benchmarks. ${ }^{26}$ Such a pragmatic way of dealing with indicators at product level seems adequate for the current stage of policy making.

Although discussions about the urgent need to undertake action against ecological overshoot, including water use, take place at all institutional levels, policy making is not very specific yet. In June 2012, at Rio+20, the United Nations Conference on Sustainable Development, water scarcity was highlighted as one of the seven critical issues which need priority attention. ${ }^{27}$ But in the Outcome Document 'The Future we want' only abstract phrases on this issue can be found. E.g.: "We call for holistic and integrated approaches to sustainable development that will guide humanity to live in harmony with nature and lead to efforts to restore the health and integrity of the Earth's ecosystem". ${ }^{28}$ Not the ambitious result that the EU and others had been pressing for, according to the European Environment Agency (EEA). No detailed Sustainable Development Goals with fixed deadlines or numbers. Still, the EEA considers the outcome to be a 'modest step in the right direction' and hopes that some preliminary targets will form the basis for further negotiation within the UN. ${ }^{29}$ In his reaction Commissioner Potočnik called upon all to implement this outcome document, and "ensure that Rio+20 leads to real action for sustainable development, the green economy and poverty eradication." 30

The European Commission itself launched a Flagship initiative 'A resource efficient Europe' under the Europe 2020 strategy in 2011. In this document the Commission on the one hand stresses that resource efficiency is an increasing global concern. On the other hand the Communication shows that the problem of (fresh) water scarcity is a European problem too: an increasing share of the EU is waterstressed and droughts are more frequent and

25 http://ec.europa.eu/environment/eussd/pdf/footprint/PEF\%20methodology \%20final\%20draft.pdf.

26 http://www.anec.eu/attachments/ANEC-ENV-2012-G-008final\%20(3).pdf.

$27 \mathrm{http}: / /$ www.uncsd2012.org/index.php?menu=123\#water.

28 http://www.uncsd2012.org/rio20/thefuturewewant.html, p. 7.

29 http://www.eea.europa.eu/highlights/rio-20-agreement-a-modest.

$30 \mathrm{http} / / /$ europa.eu/rapid/pressReleasesAction.do?reference=MEMO/12/482\& ormat=HTML\&aged=0\&language=EN\&guiLanguage=en . 
widespread. $^{31}$ In September 2011 the Flagship initiative was laid out in the Roadmap to a Resource Efficient Europe. This Roadmap provides a milestone for water, but this only includes targets regarding the implementation of WFD River Basin Management Plans, minimising the impacts of droughts and floods in the EU and limiting the extraction of water. ${ }^{32}$ Europe is a large importer of water-intensive products like cotton, feed and coffee. In total Europe is a net importer of virtual water and Europe's water footprint actually lies mostly outside the European Union. This means that Europe is highly dependent on external water resources. So internal targets with regard to water, such as a good implementation of the WFD, are not sufficient to reduce Europe's water footprint. ${ }^{33}$

Therefore the European Parliament was right to urge the Commission to adopt, in consultation with all key stakeholders, "robust and easily understandable indicators, e.g. for land footprint, water footprint, material footprint and carbon footprint, in order to monitor progress towards the targets". ${ }^{34}$ And to call on the Commission to put forward a concrete proposal for a set of coherent, measurable, clear and verifiable sectoral targets, including an overall target, in order to implement the vision and milestones of the Roadmap, for the EU and the Member States, at the latest within a year of adoption of the relevant indicators, and to ensure that all EU policies are consistent with the targets set. ${ }^{35}$ An official stakeholder consultation is being held by the European Commission until 22 October 2012 to define resource efficiency indicators and "to gather a wide range of options and ideas on how we can best measure, monitor and communicate the inter linkages between the economy and natural resources". 36

31 COMMUNICATION FROM THE COMMISSION TO THE EUROPEAN PARLIAMENT, THE COUNCIL, THE EUROPEAN ECONOMIC AND SOCIAL COMMITTEE AND THE COMMITTEE OF THE REGIONS. A resource-efficient Europe - Flagship initiative under the Europe 2020 Strategy. Brussels, 26.1.2011, COM(2011) 21, Annex 2, p. 15

32 Communication from the Commission to the European Parliament, the Council, the European Economic and Social Committee and the Committee of the Regions. Roadmap to a Resource Efficient Europe. Brussels 20.9.2011, COM (2011) 571 final, p. 14

33 A.Y. Hoekstra. How sustainable is Europe's Water Footprint? WWI Water \& Wastewater International. Vol. 26, issue 2, p. 24-26. Retrieved from: www.wwinternational.com , October 24, 2012.

34 European Parliament Resolution of 24 May 2012 on a Resource Efficient Europe. P7_TA-PROV(2012)0223, 61: "these indicators should be based on integrated accounting tools and on consistent and widely accepted scientifically based methodologies, and should be explicitly defined so to apply throughout the EU, to policy-making and private actors alike; they should, furthermore, take the full life-cycle impacts into account and measure the resources entering the economy in order to enable all aspects of resource scarcity to be addressed, thus integrating hidden flows; cautions that the suggested resource productivity indicator will not provide the information require"m.

35 EP Resolution on a Resource efficient Europe, P7_TA-PROV(2012)0223, 62

36 http://ec.europa.eu/environment/consultations_en.htm and: Consultation Paper: Options for Resource Efficiency Indicators, p. 16. Retrieved 12
Setting specific sustainable development goals at the global level and water footprint reduction targets at the European and national level will bridge the gap between the large and complex global problem of increasing water scarcity on the one hand and policy making at EU and national level on the other. But, as was expressed in the explanatory statement of the Motion for a European Parliament resolution on a resource-efficient Europe:

"The political debate often focusses on the matter of targets and indicators. And the scientific world has worked and continues working on the further development of these. Indeed, we need to get the data right. But we already know enough about the direction to take. We cannot afford waiting for the perfect indicators and targets, which always seem to be reachable within a few years. We do have sufficient knowledge to politically move forward now."37

\section{A Water Label?}

What steps should be taken to do so? The European Commission announces to assess and propose "better demand management through economic instruments (pricing, water allocation) and use of labelling and certification schemes measuring life-cycle impact and virtual water content of products" in 2012. ${ }^{38}$ The Analysis associated with the Roadmap states that "lifecycle measurement of water use (within and outside the EU) by companies for the products they produce can identify water risks and opportunities. Labelling and certification schemes can enhance market rewards for reduced life-cycle consumption."39 Indeed certification and labelling may result in a shift towards consumption of less water intensive products and these instruments seem to be within reach on a short term.

Whether they will result in an actual reduction of the water foot print cannot be predicted yet. Assessing the effectiveness of certification schemes is difficult. ${ }^{40}$ According to a recent report on the roles and limitations of certification, it "is best seen as one instrument in a portfolio of tools. It is effective in bringing about rapid changes in production practices when market-leading firms use it to verify and enforce contractual requirements for better practice and performance by their suppliers. [...] Other tools, including regulatory mandates and incentives are

http://ec.europa.eu/environment/consultations/pdf/consultation_resource.pdf

37 2011/2068 (INI), p. 16.

38 Communication from the Commission tot the European Parliament, the Council, the European Economic and Social Committee and the Committee of the Regions. Roadmap to a Resource Efficient Europe. Brussels 20.9.2011, COM (2011) 571 final, p. 14.

39 Analysis associated with the Roadmap to a Resource Efficient Europe Part II, Brussels, 20.9.2011, SEC(2011) 1067 final, p. 36.

40 Certification and biodiversity. Exploring improvements in the effectiveness of certification schemes on biodiversity. KPMG Advisory N.V. January 2012.
} 
better situated to influence the parts of the market in which certification is less attractive, less well understood or unimportant to consumers and producers. " 41

So - as often - a mix of instruments will be the most effective. If development of self-regulatory instruments is too slow or their expected effectiveness is too small, the urgency of the water scarcity problem will require other instruments, like ecodesign requirements, green public procurement, product BREFs, pricing and direct regulations, e.g. import restrictions or bans. Since the legislative process often takes a long time, it is recommendable that drafting these instruments is initiated alongside development of self-regulatory instruments.

Both compulsory and self-regulatory instruments need the development of criteria and standards. This work is currently being done.

With regard to criteria, two types can be distinguished: output-based criteria and criteria describing 'best practices'. Output-based criteria have a direct link with the environmental benefit. They define limit values for outputs associated with the lifecycle stages of the product which have impacts on the environment. ${ }^{42}$ This type of criteria does not prescribe specific production processes or technologies and is more or less comparable to BATAELs (Best available techniques associated limit values), that set limits to industrial emissions. Until now criteria set for water use in the supply chain mainly prescribe 'best practices'. They require producers or market actors to adopt or ban certain practices. Although methodologies to set output-based criteria are being developed, it is too early to use these yet.

For the time being development of an adequate water footprint standard is a priority. Water already is an aspect in existing product or sector specific standards. ${ }^{43}$ And several initiatives for standardization of indirect water use are in progress: e.g. the Alliance for Water Stewardship ${ }^{44}$ and ISO $14046^{45}$. These standards can be used in B2B (business to business) relations, but also in $\mathrm{B} 2 \mathrm{C}$ (business to consumer) relations through labelling. Explicitly included in an

41 Steering Committee of the State-of-Knowledge Assessment of Standards and Certification. (2012). Toward sustainability: The roles and limitations of certification. (Executive summary). Washington, DC: RESOLVE, Inc. p. 1415.

42 EU Ecolabel for food and feed products - feasibility study (ENV.C.1/ETU/2010/0025) Oakdene Hollins Research \& Consulting. October 2011, p. 37. Retrieved from: http://ec.europa.eu/environment/ecolabel/documents/Ecolabel_for_food_fina I report.pdf (September 27, 2012).

$43 \mathrm{http}: / / \mathrm{www}$.isealalliance.org/about-standards/sectors-covered/water (viewed 9 October 2012).

44 http://www.allianceforwaterstewardship.org/what-we-do.html\#waterstewardship-standard (viewed October 9, 2012).

45 http://www.iso.org/iso/home/store/catalogue_tc/catalogue_detail.htm?csnu mber $=43263$. existing label such as the EU Ecolabel (when the scope of this label will be extended to food) or by introducing a specific water label. Nowadays consumers often get lost in the jungle of labels and environmental claims on products. ${ }^{46}$ So another new label may not be effective. On the other hand, however, no approach to aggregate different environmental impacts to an overall net environmental impact is available yet. ${ }^{47}$ Besides, a separate label may raise more public awareness of the consequences of indirect water use. So a Water label is a good first step and can be incorporated in an integral Ecolabel or sustainability label later.

\section{Conclusion}

Water scarcity is an urgent and increasing global problem. Reduction of the water footprint of products we consume can contribute to mitigation of this problem. At this moment it is not clear what is a sustainable water footprint, neither at the global nor the individual level, but there is general agreement that it is important to reduce the amount of freshwater used for the products we consume, especially in water stressed areas.

To achieve such a reduction it is recommended to introduce:

- 1) (uniform) indicators of indirect water use in the supply chain and water footprint reduction targets at the EU level;

- 2) a (uniform) standard for (more) sustainable indirect water use; and

- 3) a separate water label

Indicators have been developed and development of standards is in progress. So certification and labelling with regard to the water footprint of products seems to be within reach. At the same time however regulatory instruments should be initiated in order to create an effective mix of instruments. Hopefully the proposals announced by the European Commission will soon start that process.

46 See for an overview of existing ecolabels: http://www.ecolabelindex.com/downloads/Global_Ecolabel_Monitor2010 .pdf.

47 EU Ecolabel for food and feed products - feasibility study (ENV.C.1/ETU/2010/0025) Oakdene Hollins Research \& Consulting. October 2011, p. 37. Retrieved from: http://ec.europa.eu/environment/ecolabel/documents/Ecolabel_for_food_fina I_report.pdf (September 27, 2012), p. 67.

$\bar{A}$ step in the direction of an integrated footprint is the 'Footprint Family', "a set of indicators - characterized by a consumption - based perspective able to track human pressure on the surrounding environment, where pressure is defined as appropriation of biological natural resources and $\mathrm{CO}^{2}$ uptake, emission of GHGs, and consumption and pollution of global freshwater resources. Three key ecosystem compartments are monitored, namely the biosphere, atmosphere, and hydrosphere through the Ecological, Carbon and Water Footprint, respectively". See: Integrating Ecological, Carbon and Water footprint into a "Footprint Family" of indicators: Definition and role in tracking human pressure on the planet. $A$. Galli et al. Ecological Indicators vol. 16 (2012) 100-112. Retrieved from: http://www.waterfootprint.org/Reports/Galli-et-al-2012.pdf (October 9, 2012). 


\section{Imprint}

Editors: Regine Barth, Nicola Below, Claudia Fricke, Martin Führ, Gerhard Roller, Julian Schenten, Silvia Schütte

Editors in charge of the current issue:

Martin Führ and Julian Schenten

Editor in charge of the forthcoming issue:

Gerhard Roller (gerhroller@aol.com)

The Editors would like to thank Vanessa Cook (ÖkoInstitut) for proofreading the elni Review.

We invite authors to submit manuscripts to the Editors as files by email using an IBM-compatible word processing system.
The elni Review is the double-blind peer reviewed journal of the Environmental Law Network International. It is distributed twice a year at the following prices: commercial users (consultants, law firms, government administrations): $€ 52$; private users, students, libraries: $€ 30$. Non-members can order single issues at a fee of $€ 20$ incl. packaging. The Environmental Law Network International also welcomes an exchange of articles as a way of payment. The elni Review is published with financial and organisational support from Öko-Institut e.V., and the Universities of Applied Sciences in Darmstadt and Bingen.

The views expressed in the articles are those of the authors and do not necessarily reflect those of elni.

\section{Authors of this issue}

Ana Barreira, Director of Instituto Internacional de Derecho y Medio Ambiente (IIDMA), LL.M on Environmental Law (London University 1993) and on International Legal Studies (New York University, 1996). Member of the IUCN Commission on Environmental Law, ana.barreira@iidma.org.

Anaïs Berthier, staff attorney at ClientEarth, an organisation of activist lawyers committed to securing a healthy planet. More info: http://www.clientearth.org, info@clientearth.org.

Peter De Smedt, Lawyer at Ghent based Environmental law firm LDR, research collaborator at the Centre for Environmental and Energy Law of Ghent University More, Member of the Flemish High Council for Environmental Enforcement on behalf of the Flemish Council for the Environment and Nature. More info: http://www.ldr.be/, peter.desmedt@1dr.be.

Martin Führ, Professor of public law, legal theory and comparative law, Society for Institutional Analysis (sofia), Darmstadt University of Applied Sciences, Germany, www.sofia-research.com, fuehr@sofia-darmstadt.de.

Catherine Ganzleben, $\mathrm{PhD}$, Senior Policy Advisor, Milieu. More info: www.milieu.be, catherine.ganzleben@milieu.be.

Almut Gaude, Bund für Umwelt und Naturschutz Deutschland (BUND) (Friends of the Earth Germany), almut.gaude@bund.net.

Steffen Foss Hansen, PhD, Senior Researcher in Risk assessment and regulation at DTU Environment, Technical University of Denmark, sfha@env.dtu.dk.
Thomas Ormond, Dr. iur., legal officer with the regional environmental administration (Regierungspräsidium Darmstadt) in Frankfurt am Main; from 2004-2008 seconded national expert for waste shipment matters with the EU Commission (DG Environment), thomas.ormond@rpda.hessen.de.

Eckard Rehbinder, Professor emeritus of economic law, environmental law and comparative law, Research Centre for Environmental Law, Goethe University Frankfurt/Germany, rehbinder@jur.uni-frankfurt.de.

Marga Robesin, lawyer at Stichting Natuur en Milieu (Dutch Society for Nature and Environment, www.natuurenmilieu.nl ) in Utrecht (The Netherlands) and $\mathrm{PhD}$ candidate at ACELS (Amsterdam Centre for Environmental Law and Sustainability), University of Amsterdam, m.a.robesin@uva.nl.

Julian Schenten, Lawyer with media and information technology speciality, Research assistant at the Society for Institutional Analysis (sofia), Darmstadt University of Applied Sciences, Germany, schenten@sofia-darmstadt.de.

Hendrik Schoukens, $\mathrm{PhD}$-assistent at Ghent University and Lawyer at the Ghent based environmental law firm LDR. More info http://www.ldr.be/, hendrik.schoukens@ugent.be.

Sarolta Tripolszky, Biodiversity, Water and Soil policy officer at the European Environmental Bureau (EEB), saroltapolszky@yahoo.co.uk.

Tania Van Laer, practising lawyer at LDR lawyers (www.ldr.be) - a law firm based in Ghent - and researcher at the Centre for Environmental \& Energy Law at the University of Ghent, tania.vanlaer@ldr.be. 


\section{elni membership}

If you want to join the Environmental Law Network International, please use the membership form on our website: http://www.elni.org or send this form to the elni Coordinating Bureau, c/o IESAR, FH Bingen, Berlinstr. 109, 55411 Bingen, Germany, fax: +49-6721-409 110, mail: Roller@fh-bingen.de.

The membership fee is $€ 52$ per year for commercial users (consultants, law firms, government administration) and $€ 21$ per year for private users and libraries. The fee includes the bi-annual elni Review. Reduced membership fees will be considered on request.

Please transfer the amount to our account at Nassauische Sparkasse - Account no.: 146060 611, BLZ 510 500 15, IBAN: DE50 5105001501460606 11; SWIFT NASSDE55.

"Yes, I hereby wish to join the Environmental Law Network International."

Name:

Organisation:

Profession:

Street:

City:

Country:

Email:

Date: 


\section{/ Óko-Institut e.V. Institut für angewandte Ökologie Institute for Applied Ecology}

The Öko-Institut (Institut für angewandte Ökologie - Institute for Applied Ecology, a registered non-profitassociation) was founded in 1977. Its founding was closely connected to the conflict over the building of the nuclear power plant in Wyhl (on the Rhine near the city of Freiburg, the seat of the Institute). The objective of the Institute was and is environmental research independent of government and industry, for the benefit of society. The results of our research are made available of the public.

The institute's mission is to analyse and evaluate current and future environmental problems, to point out risks, and to develop and implement problem-solving strategies and measures. In doing so, the Öko-Institut follows the guiding principle of sustainable development.

The institute's activities are organized in Divisions - Chemistry, Energy \& Climate Protection, Genetic Engineering, Sustainable Products \& Material Flows, Nuclear Engineering \& Plant Safety, and Environmental Law.

\section{The Environmental Law Division of the Öko-Institut:}

The Environmental Law Division covers a broad spectrum of environmental law elaborating scientific studies for public and private clients, consulting governments and public authorities, participating in law drafting processes and mediating stakeholder dialogues. Lawyers of the Division work on international EU and national environmental law concentrating on waste management emission control, energy and climate protection, nuclear, aviation and planning law.

\section{Contact \\ Freiburg Head Office: \\ P.O. Box 1771 \\ D-79017 Freiburg \\ Phone +49 (0)761-4 52 95-0 \\ Fax + +49(0)761-4 529588}

Darmstadt Office:

Rheinstrasse 95

D-64295 Darmstadt

Phone +49 (0)6151-81 91-0

Fax $\quad+49(0) 6151-819133$

Berlin Office:

Schicklerstraße 5-7

D-10179 Berlin

Phone +49(0)30-40 $5085-0$

Fax $\quad+49(0) 30-405085-388$

www.oeko.de

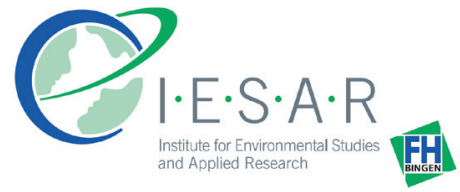

The University of Applied Sciences in Bingen was founded in 1897. It is a practiceorientated academic institution and runs courses in electrical engineering, computer science for engineering, mechanical engineering, business management for engineering, process engineering, biotechnology, agriculture, international agricultural trade and in environmental engineering.

The Institute for Environmental Studies and Applied Research (I.E.S.A.R.) was founded in 2003 as an integrated institution of the University of Applied Sciences of Bingen. I.E.S.A.R carries out applied research projects and advisory services mainly in the areas of environmental law and economy, environmental management and international cooperation for development at the University of Applied Sciences and presents itself as an interdisciplinary institution.

The Institute fulfils its assignments particularly by:

- Undertaking projects in develop-ing countries

- Realization of seminars in the areas of environment and development

- Research for European Institutions

- Advisory service for companies and know-how-transfer

\section{Main areas of research}

- European environmental policy

- Research on implementation of European law

- Effectiveness of legal and economic instruments

- European governance

- Environmental advice in developing countries

- Advice for legislation and institution development

- Know-how-transfer

- Companies and environment

- Environmental management

- Risk management

Contact

Prof. Dr. jur. Gerhard Roller

University of Applied Sciences

Berlinstrasse 109

D-55411 Bingen/Germany

Phone +49(0)6721-409-363

Fax +49(0)6721-409-110

roller@fh-bingen.de

www.fh-bingen.de

\section{sofia}

The Society for Institutional Analysis was established in 1998. It is located at the University of Applied Sciences in Darmstadt and the University of Göttingen, both Germany.

The sofia research group aims to support regulatory choice at every level of public legislative bodies (EC, national or regional). It also analyses and improves the strategy of public and private organizations.

The sofia team is multidisciplinary: Lawyers and economists are collaborating with engineers as well as social and natural scientists. The theoretical basis is the interdisciplinary behaviour model of homo oeconomicus institutionalis, considering the formal (e.g. laws and contracts) and informal (e.g. rules of fairness) institutional context of individual behaviour.

The areas of research cover

- Product policy/REACh

- Land use strategies

- Role of standardization bodies

- Biodiversity and nature conversation

- Water and energy management

- Electronic public participation

- Economic opportunities deriving from environmental legislation

- Self responsibility

sofia is working on behalf of the

- VolkswagenStiftung

- German Federal Ministry of Education and Research

- Hessian Ministry of Economics

- German Institute for Standardization (DIN)

- German Federal Environmental Agency (UBA)

- German Federal Agency for Na-ture Conservation (BfN)

- Federal Ministry of Consumer Protection, Food and Agriculture

Contact

Darmstadt Office:

Prof. Dr. Martin Führ - sofia

University of Applied Sciences

Haardtring 100

D-64295 Darmstadt/Germany

Phone +49(0)6151-16-8734/35/31

Fax +49(0)6151-16-8925

fuehr@sofia-darmstadt.de

www.h-da.de

Göttingen Office:

Prof. Dr. Kilian Bizer - sofia

University of Göttingen

Platz der Göttinger Sieben 3

D-37073 Göttingen/Germany

Phone +49(0)551-39-4602

Fax +49(0)551-39-19558

bizer@sofia-darmstadt.de 


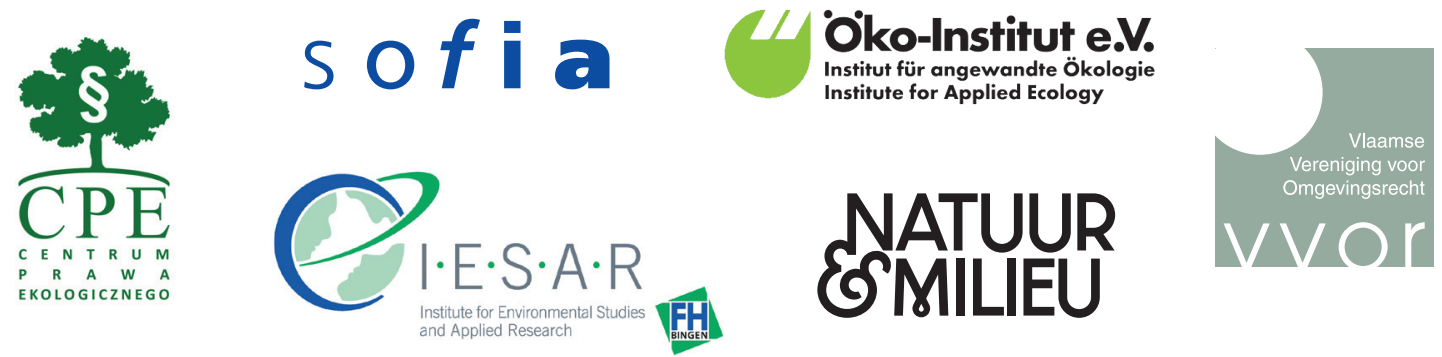

\section{elni}

In many countries lawyers are working on aspects of environmental law, often as part of environmental initiatives and organisations or as legislators. However, they generally have limited contact with other lawyers abroad, in spite of the fact that such contact and communication is vital for the successful and effective implementation of environmental law.

\section{Therefore, a group of} lawyers from various countries decided to initiate the Environmental Law Network International (elni) in 1990 to promote international communication and cooperation worldwide. elni is a registered non-profit association under German

\section{Law.}

\section{elni coordinates a number} of different activities in order to facilitate the communication and connections of those interested in environmental law around the world.

\section{Coordinating Bureau}

Three organisations currently share the organisational work of the network: Öko-Institut, IESAR at the University of Applied Sciences in Bingen and sofia, the Society for Institutional Analysis, located at the University of Darmstadt. The person of contact is Prof. Dr. Roller at IESAR, Bingen.

\section{elni Review}

The elni Review is a bi-annual, English language law review. It publishes articles on environmental law, focussing on European and international environmental law as well as recent developments in the EU Member States. elni encourages its members to submit articles to the elni Review in order to support and further the exchange and sharing of experiences with other members.

The first issue of the elni Review was published in 2001. It replaced the elni Newsletter, which was released in 1995 for the first time.

The elni Review is published by Öko-Institut (the Institute for Applied Ecology), IESAR (the Institute for Environmental Studies and Applied Research, hosted by the University

of Applied Sciences in Bingen) and sofia (the Society for Institutional Analysis, located at the University of Darmstadt).

\section{elni Conferences and Fora}

elni conferences and fora are a core element of the network. They provide scientific input and the possibility for discussion on a relevant subject of environmental law and policy for international experts. The aim is to gather together scientists, policy makers and young researches, providing them with the opportunity to exchange views and information as well as to develop new perspectives.
The aim of the elni fora initiative is to bring together, on a convivial basis and in a seminar-sized group, environmental lawyers living or working in the Brussels area, who are interested in sharing and discussing views on specific topics related to environmental law and policies.

\section{Publications series}

elni publishes a series of books entitled "Publications of the Environmental Law Network International". Each volume contains papers by various authors on a particular theme in environmental law and in some cases is based on the proceedings of the annual conference.

\section{elni Website: elni.org}

The elni website www.elni.org contains news about the network. The members have the opportunity to submit information on interesting events and recent studies on environmental law issues. An index of articles provides an overview of the elni Review publications. Past issues are downloadable online free of charge.

\section{elni Board of Directors}

- Martin Führ - Society for Institutional Analysis (sofia), Darmstadt, Germany;

- Jerzy Jendroska - Centrum Prawa Ekologicznego (CPE), Wroclaw, Poland;

- Isabelle Larmuseau - Vlaamse Vereniging voor Omgevingsrecht (VVOR), Ghent, Belgium;

- Marga Robesin - Stichting Natuur en Milieu, Utrecht, The Netherlands;

- Gerhard Roller - Institute for Environmental Studies and Applied Research (I.E.S.A.R.), Bingen, Germany. 